\title{
Isolation and Characterization of a Parasitic Nematode, Os- cheius myriophila (Nematoda: Rhabditida), Associated with European Mole Cricket, Gryllotalpa gryllotalpa (Orthoptera: Gryllotalpidae)
}

\author{
Avrupa Danaburnu Gryllotalpa gryllotalpa (Orthoptera: Gryllotal- \\ pidae) ile İlişkili Parazitik Bir Nematod Olan Oscheius myriophila \\ (Nematoda: Rhabditida)'nın İzolasyonu ve Karakterizasyonu
}

Research Article

Zeynep Erbaş, İsmail Demir*, Zihni Demirbağ

Department of Biology, Faculty of Science, Karadeniz Technical University, Trabzon, Turkey.

\section{A B S T R ACT}

\begin{abstract}
$\Lambda$ nematode strain was isolated from a population of European mole cricket, Gryllotalpa gryllotalpa L. (OrthopA tera: Gryllotalpidae), collected from the Black Sea Region of Turkey. Based on morphometrical and molecular (ITS partial sequence) properties, it was identified as Oscheius myriophila. This species of dauer juveniles resembled with Rhabditis myriophila (Poinar, 1986), however, it differs in having larger body length (571.3-693.9) and distance from the head to the nerve ring (100-116.8), and smaller tail length (53.4-76.8) and width at anus (10.4-13.8). This stage is the third-stage juvenile enclosed in a second-stage cuticle that surrounds the nematode like a sheath. The sequences of the ITS region of rDNA confirmed this identification. The species is recorded for the first time from G. gryllotalpa.
\end{abstract}

\section{Key Words}

Oscheius myriophila, Gryllotalpa gryllotalpa, parasitic nematode.

\section{öz}

u çalışmada, Türkiye'de Karadeniz Bölgesi'nden toplanan Avrupa danaburnu (Gryllotalpa gryllotalpa L. Orthoptera: Gryllotalpidae) populasyonundan bir nematod suşu izole edildi. Suş, morfometrik ve moleküler (ITS kısmi sekansı) özelliklerine göre Oscheius myriophila olarak tanımlandı. Dauer jüvenillerin bu türleri Rhabditis myriophila (Poinar, 1986)'ya benzemekle birlikte, O. myriophila sahip olduğu; vücut uzunluğu (571.3693.9) ve baştan sinir halkasına olan uzunluk (100-116.8), ve küçük kuyruk uzunluğu (53.4-76.8) ve anüs genişliği (10.4-13.8) özellikleriyle farklıdır. Bu evre, nematodu bir kılıf gibi kuşatan ikinci evre kütikül içinde bulunan üçüncü evre jüvenildir. rDNA'nın ITS bölgesinin sıraları bu tanımlamayı doğruladı. Bu tür G. gryllotalpa'da ilk kez kaydedildi.

\section{Anahtar Kelimeler}

Oscheius myriophila, Gryllotalpa gryllotalpa, parazitik nematod.

Article History: Received: Sep 3, 2016; Revised: Nov 20, 2016; Accepted: Jan 20, 2017; Available Online: Apr 1, 2017.

DOI: $10.15671 / \mathrm{HJBC} .2017 .152$

Correspondence to: i. Demir, Department of Biology, Faculty of Science, Karadeniz Technical University, Trabzon, Turkey. 


\section{INTRODUCTION}

The he European mole cricket, Gryllotalpa gryllotalpa (Linnaeus 1758), is one of the most serious insect pests in turf and field crops in both Turkey and in all over the world [1,2]. They are burrowing insects and feed on a variety of organisms in the soil. These insects do not attack plants directly, but by tunneling, extended surface tunnels, cause significant damage to grass and crops of gardens, as they chop off any roots encountered when digging [3].

Nematode-arthropod associations are plentiful and range from beneficial to antagonistic [4, 5]. These associations have been divided into four categories: phoretic (nematodes are transported by an insect), necromenic (nematodes obtain nutrition from insect cadavers), facultative parasitism, and obligate parasitism [6]. Insect parasitism evolves in this sequence, with parasites evolving from non-parasitic insect associates [6]. Nematodes also interact with bacteria in at least three ways such as trophism (nematodes eat bacteria), parasitism (pathogens cause nematode diseases if not resisted), and mutualism (nematodes and bacteria cooperate).

The Oscheius subgenus has been divided into Dolichura and Insectivora groups [7]. Sudhaus \& Hooper [7] accepted seven species of member of Rhabditis (Oscheius) subgenus under Dolichura group. R. (0.) dolichura [8], R. (O.) sechellensis [9], R. (O.) pseudodolichura [10], R. (O.) tipulae [11], R. (0.) dolichuroides [12], and $R$. (O.) guentheri [7] gave diagnosis of the subgenus Oscheius [13] of Rhabditis. While in Insectivora group they recognized five known species, $R$. (O.) caulleryi [14], R. (O.) Iucianii [14], R. (O.) insectivora [15], R. (O.) myriophila [16], R. (O.) necromena [17]. Tabassum and Shahina [18] as well as Tahseen and Nisa [19] recognized Oscheius as genus and described Oscheius maqbooli and $O$. shamimi, respectively.

The aim of the present work was to provide a morphometric and molecular characterization of the nematode, which detected first time in the population of Gryllotalpa gryllotalpa from Turkey during a survey and to contribute to the knowledge of the species.

\section{MATERIALS and METHODS}

Nematodes were isolated from G. gryllotalpa adults and nymphs during a survey conducted in 2011 in the Eastern Black Sea Region of Turkey. Collected nymphs and adults stages of G. gryllotalpa were individually placed in plastic boxes $(17 \times 11 \times 7 \mathrm{~cm})$ including sterile soil and perforated covers to permit airflow during transit to the laboratory. Subsequently, cadavers were placed in modified White traps to allow nematode emergence according to procedures described by Kaya \& Stock [20]. Harvested nematodes (Gg1) were washed three times by sedimentation in distilled water.

For morphometric analysis of isolate $\mathrm{Gg} 1,20$ IJs were randomly selected from G. gryllotalpa cadaver. Infective juveniles were collected for one week after they first appeared from cadavers [21]. The IJs were killed and fixed by hot $4 \%$ formalin $\left(60^{\circ} \mathrm{C}\right)$ for 2 minutes and kept in this solution for $12 \mathrm{~h}$ at room temperature. Fixed nematodes were transferred to anhydrous glycerin and mounted on slides using cover-glass supports to avoid flattening them. Morphological observations were made following the taxonomic criteria by Hominick et al. [22]. Measurements were taken using a Zeiss AxioCam ERc 5s equipped with differential interference contrast optics.

Molecular characterization of the new isolate Gg1 was done by analysis of 18S internal transcribed spacer (ITS) ribosomal DNA sequences. DNA was extracted from IJs using a modified method published by Joyce et al [23].

ITS region of rDNA of nematode was amplified by PCR in a $50 \mu$ reaction mix containing: 5 $\mu \mathrm{L}$ of the DNA suspension, $5 \mu \mathrm{L}$ of 10X PCR buffer, $2 \mu \mathrm{L}$ of $\mathrm{MgCl}_{2}(25 \mathrm{mM}), 1 \mu \mathrm{L}$ of dNTP mixture (10 mM each dNTP), $1.5 \mathrm{U}$ of Taq DNA polymerase, 1 $\mu \mathrm{l}$ of the forward primer TW81: 5'-GTTTCCGTAGGTGAACCTGC-3', and $1 \mu$ of the reverse primer AB28: 5'-ATATGCTTAAGTTCAGCGGGT-3' and $\mathrm{ddH}_{2} \mathrm{O}$ to final volume [23]. Subsequently, $5 \mu \mathrm{l}$ of the product was loaded on $1 \%$ agarose gel, and a target fragment was purified using a Qiagen Gel Purification Kit (Qiagen Ltd, The Netherlands). 
The purified PCR product was cloned into pGEM-T easy vector and transferred to $\mathrm{DH} 1 \mathrm{O} \beta$ high efficiency competent cells (Promega, Netherlands), according to the manufacturer's instructions. After selection of transformed colonies, plasmid isolation was performed and digested by restriction enzymes to confirm whether the gene was successfully cloned into the vector or not. Plasmid DNA samples that had the right clone were sequenced (Macrogen, Korea). The obtained sequence of Oscheius isolate was compared with sequences of the Oscheius species available in GenBank (NCBI). The DNA sequences were edited by BioEdit [24] with sequences of related species and new isolates available in GenBank. The evolutionary relationship of the isolates with 4 species of Oscheius and 2 species of Rhabditis were evaluated [25]. Phylogenetic analyses (Maximum Parsimony analyses) of sequence data were done using MEGA [26].

\section{RESULTS}

The morphometrical examination of dauer juveniles of nematode isolate Gg1 matched with the original descriptions of the respective species ( $\mathrm{Ta}$ ble 1). This species of dauer juveniles resembled with Rhabditis myriophila [16], however, it differs in having larger body length (571.3-693.9) and distance from the head to the nerve ring (100-116.8), and smaller tail length (53.4-76.8) and width at anus (10.4-13.8) (Figure 1).

The full sequence length of the ITS1-5.8S-ITS2 region including the partial sequence of $18 \mathrm{~S}$ and 28S rRNA genes of the isolate of 0 . myriophila $\mathrm{Gg} 1$ was 1148 bp. The BLAST search indicated a 99\% similarity among the 0 . myriophila $\mathrm{Gg} 1$ isolate sequence and isolate from USA (AY602176). Multiple sequence alignments of the ITS rDNA region of Oscheius and Rhabditis species are presented

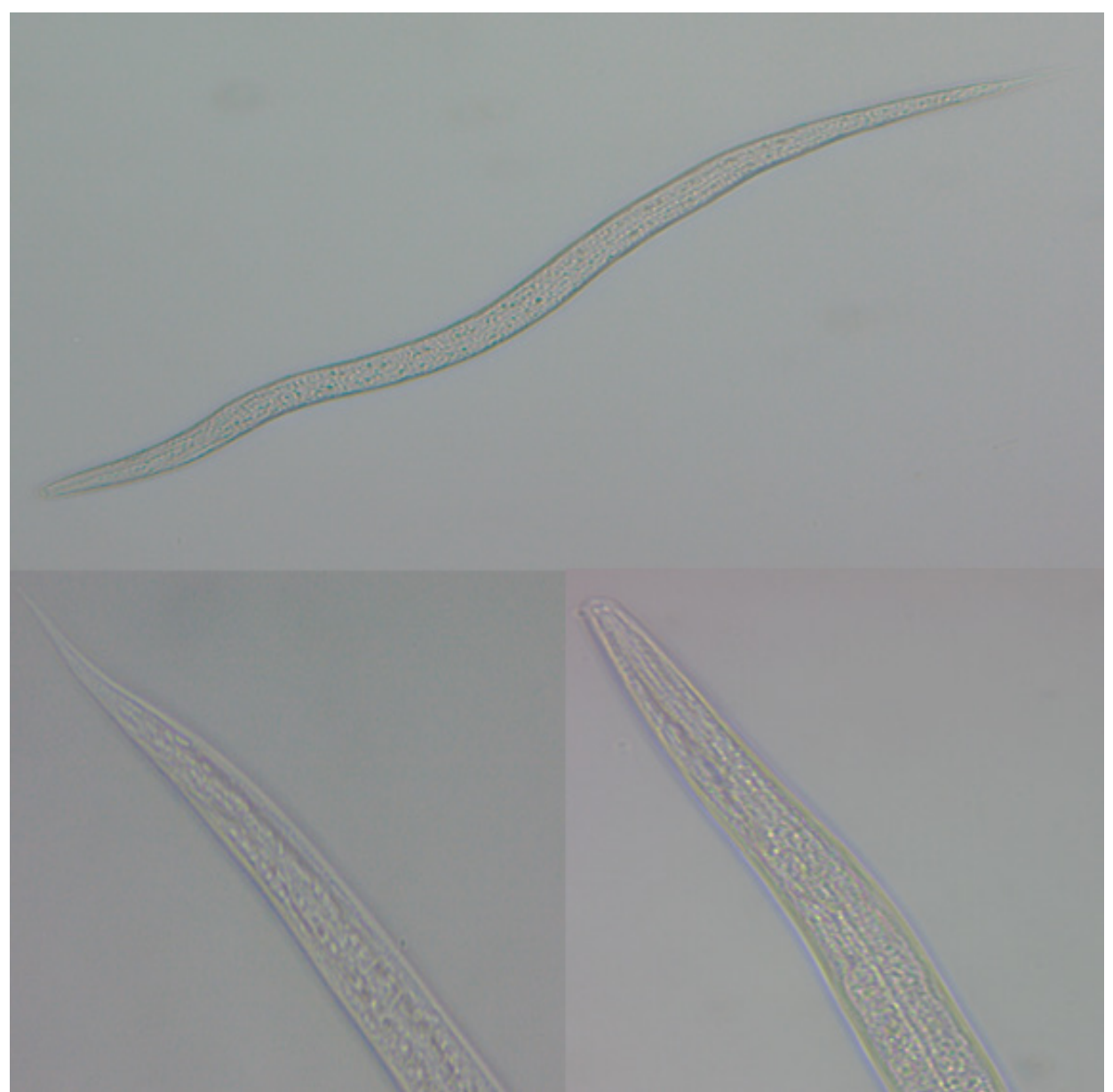

Figure 1. Light microphotographs of Oscheius myriophila Gg1. A: Length of an infective juvenile. B: Tail of an Infective juvenile. C: Head of an infective juvenile. 
Table 1. Morphometrics data of Oscheius myriophila Gg1. All measurements are in $\mu \mathrm{m}$ and in the form: $\mathrm{mean} \pm \mathrm{SD}$ ( $\mathrm{range}$ ).

\begin{tabular}{|c|c|c|c|c|c|}
\hline \multirow{3}{*}{$\frac{\text { Isolates }}{\text { Species }}$} & \multicolumn{5}{|c|}{ Infective Juveniles } \\
\hline & \multirow{2}{*}{ O. pheropsophi' } & \multirow{2}{*}{ O. colombiana ${ }^{2}$} & \multirow{2}{*}{ O. amsactae } & \multirow{2}{*}{ R. myriophila ${ }^{4}$} & \multirow{2}{*}{$\begin{array}{l}\text { O. myriophila } \\
\text { Gg1 }\end{array}$} \\
\hline & & & & & \\
\hline $\mathrm{n}$ & 16 & 25 & 10 & 6 & 20 \\
\hline$L$ & $\begin{array}{c}568 \pm 50 \\
(491-643)\end{array}$ & $\begin{array}{c}505 \pm 32 \\
(439-535)\end{array}$ & $335-409$ & $\begin{array}{c}564 \\
(504-611)\end{array}$ & $\begin{array}{c}630.2 \pm 31,5 \\
(571.3-693.9)\end{array}$ \\
\hline W & $\begin{array}{l}24 \pm 2.5 \\
(22-31)\end{array}$ & $\begin{array}{c}23 \pm 3 \\
(19-28)\end{array}$ & $14.2-16.5$ & $\begin{array}{c}23 \\
(19-26)\end{array}$ & $\begin{array}{l}25.4 \pm 2.7 \\
(21-30.4)\end{array}$ \\
\hline EP & $\begin{array}{c}136 \pm 7 \\
(124-148)\end{array}$ & $\begin{array}{c}96 \pm 11 \\
(82-116)\end{array}$ & 68.7-82.0 & $\begin{array}{c}107 \\
(97-114)\end{array}$ & $\begin{array}{c}108 \pm 6.7 \\
(97.8-118.8)\end{array}$ \\
\hline NR & $\begin{array}{c}90 \pm 9 \\
(79-108)\end{array}$ & $\begin{array}{l}89 \pm 13.5 \\
(73-113)\end{array}$ & $59.2-69.5$ & $\begin{array}{c}89 \\
(83-96)\end{array}$ & $\begin{array}{c}110.5 \pm 4.9 \\
(100-116.8)\end{array}$ \\
\hline ES & $\begin{array}{c}130 \pm 6 \\
(120-141)\end{array}$ & $\begin{array}{c}118 \pm 12 \\
(98-139)\end{array}$ & $90.8-97.9$ & $\begin{array}{c}129 \\
(126-136)\end{array}$ & $\begin{array}{c}134.6 \pm 3.2 \\
(128.8-139.8)\end{array}$ \\
\hline ABW & $\begin{array}{c}15 \pm 2 \\
(11-19)\end{array}$ & $\begin{array}{c}13 \pm 3.5 \\
(9.5-20)\end{array}$ & $7.9-11.1$ & $\begin{array}{c}15 \\
(14-16)\end{array}$ & $\begin{array}{c}12.3 \pm 1 \\
(10.4-13.8)\end{array}$ \\
\hline $\mathrm{T}$ & $\begin{array}{c}88 \pm 13 \\
(64-106)\end{array}$ & $\begin{array}{c}56 \pm 6 \\
(48-66)\end{array}$ & $48.9-60.4$ & $\begin{array}{c}78 \\
(75-80)\end{array}$ & $\begin{array}{c}82.1 \pm 6.2 \\
(72.2-92.2)\end{array}$ \\
\hline a & $\begin{array}{c}23 \pm 2 \\
(19-27)\end{array}$ & $\begin{array}{c}22.5 \pm 3.5 \\
(17-27)\end{array}$ & $21.8-26.5$ & NA & $\begin{array}{c}25 \pm 2.2 \\
(20.5-28.5)\end{array}$ \\
\hline$b$ & $\begin{array}{c}4 \pm 0.4 \\
(3.7-5.2)\end{array}$ & $\begin{array}{l}4.3 \pm 0.6 \\
(3.2-5.4)\end{array}$ & $3.5-4.3$ & NA & $\begin{array}{c}4.7 \pm 0.2 \\
(4.3-5.2)\end{array}$ \\
\hline c & $\begin{array}{c}6.6 \pm 1 \\
(5.2-8.6)\end{array}$ & $\begin{array}{c}9.2 \pm 1.3 \\
(6.6-11.1)\end{array}$ & $6.6-7.4$ & NA & $\begin{array}{c}9.3 \pm 0.9 \\
(8.3-11.6)\end{array}$ \\
\hline
\end{tabular}

NA: not available, n: number of specimens, L: total body length, EP: distance from anterior end to base excretory pore, NR: distance from anterior end to nerve ring, ES: distance from anterior end base of basal bulb, T: tail length, ABW: anal body width, W: maximum body width, a: L/W, b: L/ES, c: L/T. ${ }^{1}[27],{ }^{2}[30],{ }^{3}[33],{ }^{4}[16]$.

in Figure 2. The evolutionary relationship of the isolate and closely related other species were evaluated. Sequence and phylogenetic analysis of 1148 bp segment of ITS rDNA by MEGA revealed a high degree of homology to genus of Oscheius and Rhabditis (Figure 3).

\section{DISCUSSION}

A new nematode was first isolated from European mole crickets and Turkey. Based on the taxonomical characteristics; the nematode isolate was identified as Oscheius myriophila.

According to morphologic data, dauer juvenile of 0 . myriophila $\mathrm{Gg} 1$ isolate was similar to the Rhabditis myriophila [16], however, differs in having larger body length $(L=571.3-693.9 \mu \mathrm{m})$ and larger distance from anterior end to nerve ring $(\mathrm{NR}=100-116.8 \mu \mathrm{m})$.

The new isolate (dauer juvenile) also closely resembles 0 . pheropsophi [27] but differs in body length $(L=571.3-693.9 \mu \mathrm{m}$ vs. $L=491-643 \mu \mathrm{m}$ in
O. pheropsophi); shorter distance from anterior end to base excretory pore $(E P=97.8-118.8 \mu \mathrm{m}$; $\mathrm{EP}=124-148 \mu \mathrm{m}$ in 0 . pheropsophi). New isolate is larger in body length $(571.3-693.9 \mu \mathrm{m})$ and distance from anterior end base of basal bulb (128.8$139.8 \mu \mathrm{m}$ ) than 0 . pheropsophi, O. colombiana, $O$. amsactae and $R$. myriophila (Table 1).

The genus Rhabditis [28] includes several nematode species are associated with soil invertebrates. Several of species of the genus Oscheius were recorded from cadaver/soil like Rhabditis (O.) tipulae re-described by Sudhaus [29] associated with leather jackets larva of Tipula paludosa (Diptera: Tipulidae), R. (O.) myriophila [16]; Rhabditis (O.) columbiana [30] associated with burrower bug, Cyrtomenus bergi (Hemiptera: Cydnidae). R. caulleryi [14] and R. myriophila [16] also cultured from millipedes [17], $R$. (O.) necromena [17] associated with millipede Oncocladosoma castaneum (Diplopoda: Paradoxosomatidae), $R$. (0.) pheropsophi [27] associated with bombardier beetle, Pheropsophus aequinoctialis L. are shown to be of economic importance as a biological con- 


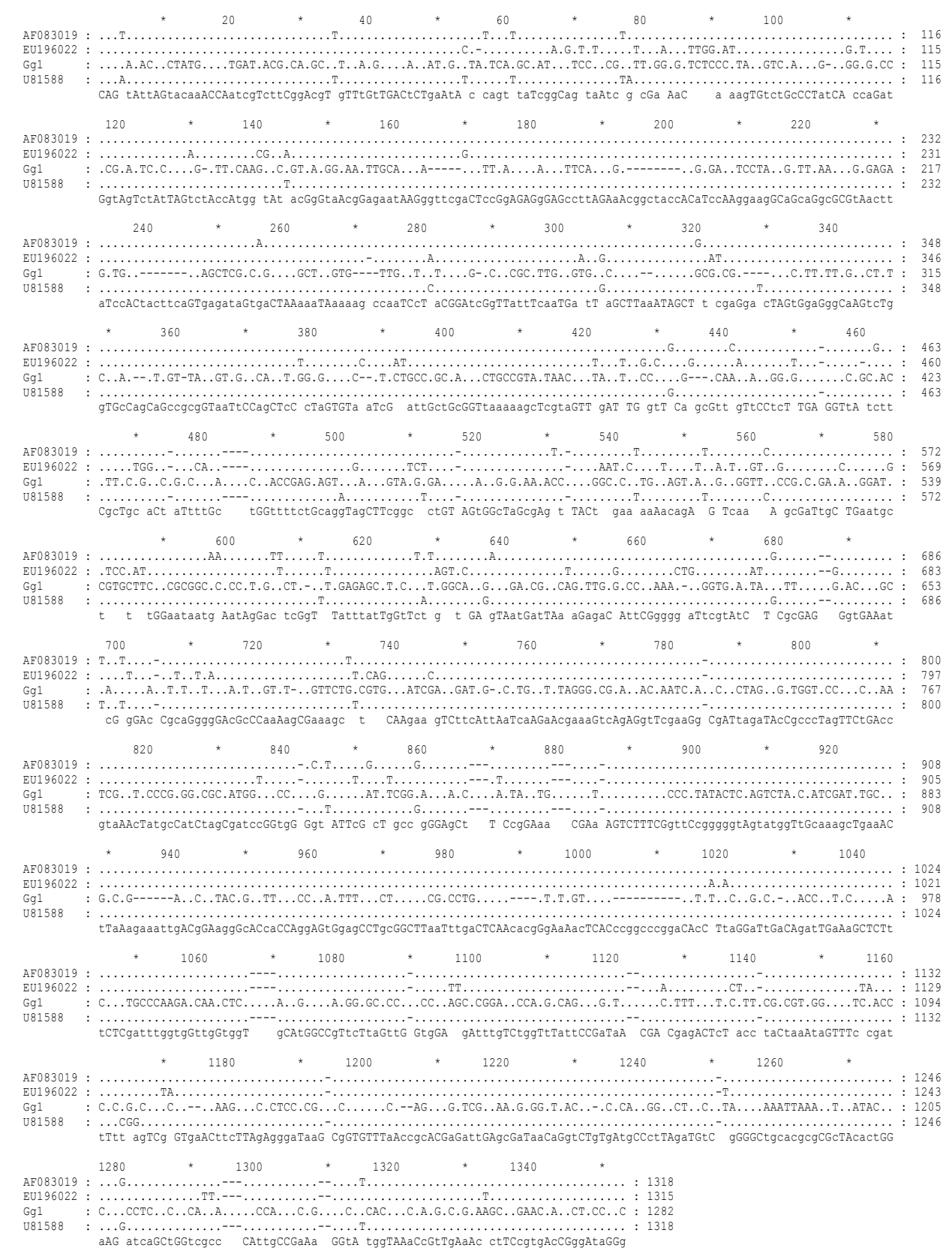

Figure 2. Multiple sequence alignment of the ITS rDNA region of Oscheius and Rhabditis species. Code Gg1 corresponds to the isolate of Oscheius myriophila. Codes AF083019 and EU196022 refer to Oscheius insectivora and Oscheius guentheri strains, respectively. Code U81588 corresponds to the Rhabditis myriophila strain. Sequence alignments were performed using the ClustalW-algorithm.

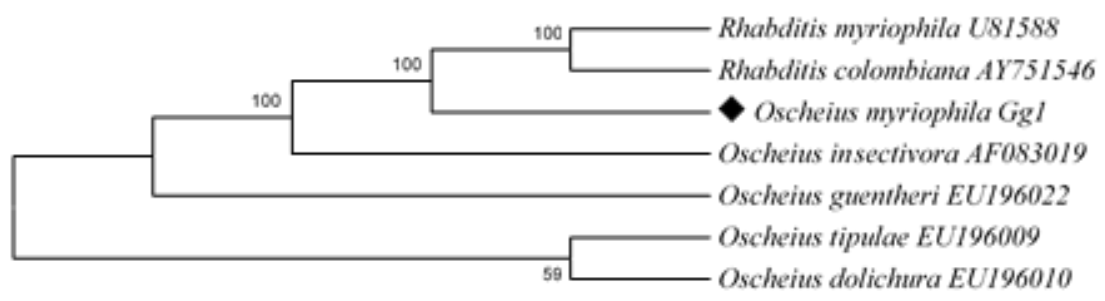

Figure 3. Phylogenetic relationships of the Oscheius and Rhabditis species based on analysis of ITS rDNA regions neighbor joining method. Number on braches more than $70 \%$ indicates the percentage of 1000 bootstrap replicates. 
trol agent. While R. (O.) maqbooli [18] and R. (O.) shamimi [19] were recovered from soil and $R$. (O.) guentheri [7] was isolated from decaying rice plants. R. (O.) amsactae was also recovered from cadaver of red-hairy caterpillar. We described a new isolate, Oscheius myriophila Gg1, as an associate of the European mole cricket, Gryllotalpa gryllotalpa.

Some Oscheius species such as O. carlianonsis [31], O. siddiqii, O. niazii [32] and O. amsactae [33] were currently reported as enthomopathogenic nematode. Furthermore 0 . gingeri was also trapped by baiting with $G$. mellonella from the soil like enthomopathogenic nematode. All of which increase the importance of our isolate. Considering that the findings of this study will contribute significantly to integrated pest management of mole crickets and under soil pests such as Agrotis segetum, Agriotes lineatus and Melolontha melolontha [34-37]. Future work will indicates the potential role of this nematode in natural regulation of mole crickets.

\section{References}

1. J.H. Frank, J.P. Parkman, Integrated pest management of pest mole crickets with emphasis on the southeastern USA, Integrated Pest Management Reviwevs, 4 (1999) 39-52.

2. Ministry of Agriculture of Turkey, The Agricultural Control Technical Recommendations, Vol 3, Basak Publisher, Ankara (2008).

3. M.H. Kazemi, S. Jafari, H. Lotfalizadeh, M. Jafarloo, Evaluation on morphological characters of European mole cricket, Gryllotalpa gryllotalpa (Orth.: Gryllotalpidae) in the North-west of Iran, Journal of Agricultural Science, 14 (2010) 63-73.

4. G.O. Poinar, The Natural History of Nematodes. Prentice Hall, Inc., New Jersey (1983).

5. R. Gaugler, H.K. Kaya, Entomopathogenic nematodes in biological control, Boca Raton, CRC Press (1990).

6. W. Sudhaus, Evolution of Insect Parasitism in Rhabditid and Diplogastrid Nematodes. Advances in Arachnology and Developmental Biology. Inst. Zool., Belgrade; BAS, Sofia; Fac. Life Sci., Vienna; SASA, Belgrade \& UNESCO MAB, Serbia, Vienna-Belgrade-Sofia, Monographs, 12 (2008) 143-161.

7. W. Sudhaus, D.J. Hooper, Rhabditis (Oscheius) guentheri sp.n., an unusual species with reduced posterior ovary, with observations on the Dolichura and Insectivora groups (Nematoda: Rhabditidae), Nematologica, 40 (1994) 508-533.

8. A.F. Schneider, Monographie der nematoden, Berlin (1866).
9. F.A. Potts, Notes on the free living nematodes, Quarterly Journal of Microscopical Science, 55 (1910) 433485.

10. G. Osche, Systematik und phylegenie der gattung Rhabditis (Nematoda), Zoologische Jahrabucher (Systematik), 81 (1952) 175-312.

11. A.B.Q. Lam, J.M.C. Webster, Morphology and biology of Panagrolaimus tipulae n. sp. (Panagrolaimidae) and Rhabditis (Rhabditella) from leather jacket larvae, Tipula paludosa (Diptera; Tipulidae), Nematology, 17 (1971) 201-212.

12. R.V. Anderson, W. Sudhaus, Description of Rhabditis (Pellioditis) dolichuroides n. sp. (Nematoda: Rhabditidae) from Kenya, Canadian Journal of Zoology, 63 (1985) 1711-1715.

13. I. Andrassy, Evolution as a basis of the systematization of nematodes, London, UK, Pitman (1976).

14. E. Maupas, Essaia d hybridation chez les nematodes, Bulletin Biologigue France et Belgigue, 52 (1919) 466498.

15. H. Korner, Die Nematoden fauna des vergenebden Holzes und ihre Beziehung zu den Insekten, Zoologische Jahrabucher (Systematik), 82 (1954) 245-353.

16. G.O. Poinar, Rhabditis myriophila sp. N. (Rhabditidae: Rhabditida), Associated with the Millipede, Oxidis gracilis (Polydesmida: Diplopoda), Proceedings of the Helminthological Society of Washington, 53 (1986) 232-236.

17. W. Sudhaus, F. Schulte, Rhabditis (Rhabditis) necronema sp. n., (Nematoda: Rhabditidae), from southern Australian diplopoda with notes on its riblings $R$. myriophila, Poinar, 1986 and R. caulloryi, Maupas, 1919, Nematologica, 35 (1989) 15-24.

18. K.A. Tabassum, F. Shahina, Oscheius maqbooli n. sp., and observation on three known Rhabditis species (Nemata: Rhabditida) from sugarcane fields of Balochistan, Pakistan, Pakistan Journal of Nematology, 20 (2002) 1-21.

19. Q.Tahseen, S. Nisa, Embryology and gonad development in Oscheius shamimi sp. n. (Nematoda: Rhabditida), Nematology, 8 (2006) 211-221.

20. H.K. Kaya, S.P. Stock, Techniques in Insect Nematology. In: Lacey, L.A. (Ed.). Manual of Techniques in Insect Pathology, London, Academic Press (1997).

21. K.B. Nguyen, G.C. Smart, Morphometrics of infective juveniles of Steinernema spp. and Heterorhabditis bacteriophora (Nemata: Rhabditida), Journal of $\mathrm{Ne}$ matology, 27 (1995) 206-212.

22. W.M. Hominick, B.R. Briscoe, F.G. del Pino, J. Heng, D.J. Hunt, E. Kozodoy, Z. Mracek, K.B. Nguyen, A.P. Reid, S. Spiridonov, P. Stock, D. Sturhan, C. Waturu, M. Yoshida, Biosystematics of entomopathogenic nematodes: current status, protocols and definitions, Journal of Helminthology, 71 (1997) 271-298.

23. S.A. Joyce, A. Reid, F. Driver, J. Curran, Application of polymerase chain reaction (PCR) methods to identification of entomopathogenic nematodes. In: Burnell, A.M., Ehlers, R.U., Masson, J.P. (Eds.). Biotechnology: Genetics of Entomopathogenic Nematode Bacteria Complexes, DG XII, Luxembourg, European Commission, (1994) 178-187.

24. T.A. Hall, BioEdit: a user-friendly biological sequence alignment editor and analysis program for Windows 95/98/NT, Nucleic Acids Symposium Series, 41 (1999) 95-98. 
25. D.L. Swofford, PAUP/ Phylogenetic Analysis Using Parsimony (and other methods). Sinauer Associates, Sunderland, Massachusetts (2002).

26. K. Tamura, J. Dudley, M. Nei, S. Kumar, MEGA4: Molecular evolutionary genetics analysis (MEGA) software version 4.0, Molecular Biology and Evolution, 24 (2007) 1596-1599.

27. G.C. Smart, K.B. Nguyen, Rhabditis (Oscheius) pheropsophi n. sp. (Rhabditida: Rhabditidae), Journal of Nematology, 26 (1994) 19-24.

28. F. Dujardin, Historie naturella des helminthes on vers intestinaux, Paris, 654 (1845).

29. W. Sudhaus, Redescription of Rhabditis (Oscheius) tipulae (Nematoda: Rhabditidae) associated with leatherjackets, larvae of Tipula paludosa (Diptera: Tipulidae), Nematologica, 39 (1993) 234-239.

30. S.P. Stock, A.M. Caicedo, P.A. Calatayud, Rhabditis (Oscheius) colombiana n. sp. (Nematoda: Rhabditida), a necromenic associate of the subterranean burrower bug Cyrtomenus bergi (Hemiptera: Cydnidae) from the Cauca Valley, Colombia, Nematology, 7 (2005) 363-373.

31. Y.E. Weimin, A.T. Barragan, Y.Z. Cardoza, Oscheius carolinensis n. sp. (Nematoda: Rhabditidae), a potential entomopathogenic nematode from vermicompost, Nematology, 12 (2010) 121-135.

32. K.A. Tabassum, F. Shahina, Oscheius maqbooli n. sp., and observation on three known Rhabditis species (Nemata: Rhabditida) from sugarcane fields of Balochistan, Pakistan, Pakistan Journal of Nematology, 20 (2002) 1-21.
33. S.S. Ali, R. Pervez, R. Andrabi, R. Sharma, V. Verma, Oscheius amsactae n. sp. (Nematoda: Rhabditida), a necromenic associate of red hairy caterpillar, Amsacta moori (Lepidoptera: Arctiidae) from Kanpur, India, Archives of Phytopathology and Plant Protection, 44 (2011) 871-881.

34. A. Sevim, Z. Demirbağ, i. Demir, A new study on the bacteria of Agrotis segetum Schiff. (Lepidoptera: Noctuidae) and their insecticidal activities, Turkish Journal of Agriculture and Forestry, 34 (2010) 333-342.

35. M. Danışmazoğlu, í. Demir, A. Sevim, Z. Demirbağ, R. Nalçacıoğlu, An investigation on the bacterial flora of Agriotes lineatus (Coleoptera: Elateridae) and pathogenicity of the flora members, Crop Protection, 40 (2012) 1-7.

36. C. Gökçe, H. Yılmaz, Z. Erbaş, Z. Demirbağ, i. Demir, First Record of Steinernema kraussei (Rhabditida: Steinernematidae) from Turkey and Its Virulence against Agrotis segetum (Lepidoptera: Noctuidae), Journal of Nematology, 45 (2013) 253-259.

37. Z. Erbaş, C. Gökçe, S. Hazır, Z. Demirbağ, İ. Demir, Isolation and identification of entomopathogenic nematodes from The Eastern Black Sea Region and their biocontrol potential against Melolontha melolontha (Coleoptera: Scarabidae) larvae, Turkish Journal of Agriculture and Forestry, 38 (2014) 187-197. 
